\title{
PENGARUH MENGKONSUMSI AIR HANGAT SEBELUM PEMBERIAN NEBULIZER TERHADAP PENINGKATAN KELANCARAN JALAN NAPAS PADA PASIEN ASMA BRONKIAL
}

\section{RAHMAD GURUSINGA ${ }^{1}$, FREDY KALVIN TARIGAN ${ }^{2}$, RUTH MARGARETHA SITANGGANG ${ }^{3}$}

\author{
1,2,3 Institut Kesehatan MEDISTRA Lubuk Pakam \\ Jl. Sudirman No 38 Lubuk Pakam Kab.Deli Serdang, Sumatera Utara. \\ e-mail : rahmad.gurusinga@gmail.com
}

DOI $10.35451 / j k k . v 3 i 2.645$

\begin{abstract}
Warm drinking water is one of the non-pharmacological therapies that can have an oxygenation effect on the body, especially in the respiratory organs so that it can help clear the airway in bronchial asthma patients who experience respiratory problems due to obstruction or other trigger factors such as allergic reactions, viral infections, and air pollution. Warm drinking water is the right therapy for bronchial asthma patients because by drinking warm water the particles trigger tightness and the liquid or mucus in the bronchioles will be broken down. Nebulizer is one of the inhalations with the administration of drugs in the form of steam that is given through inhalation, the nebulizer can help provide relaxation to help loosen breathing in bronchial asthma patients. This goal is to see the smoothness of the airway before and after in the two groups with treatment treatment in the intervention group and not giving treatment to the control group. The population in this study were bronchial asthma patients who were treated at the Grandmed Lubuk Pakam Hospital. The results of the study with the Paired Sample statistical test $t$-test design of airway smoothness in the intervention group value ( $p$ value $=0.000<a=0.05$ ), while in the control group the value ( $p$ value $=0.920>a=0.05$ ) was obtained. The conclusion of this study is that consuming warm water before offering a nebulizer to bronchial asthma patients can help smoothen the patient's airway.
\end{abstract}

Keywords : Warm drinking water, smooth airway, bronchial asthma

\section{PENDAHULUAN}

Jalan napas atau yang biasanya disebut dengan saluran pernapasan yang digunakan tubuh untuk memperoleh oksigen melalui proses ventilasi secara otomatis yang dibagi dalam dua area yaitu zona konduksi dan zona respirasi. Zona konduksi berperan sebagai tempat lewatnya udara pernapasan, membersihkan, melembabkan, dan menyamakan suhu udara denggan suhu tubuh. Zona respirasi berfungsi dalam proses pertukaran udara dengan darah (Somantri, Irman, 2009).

Terganggunya sistem pernapasan dapat berdampak buruk bagi kesehatan karena terjadinya gangguan pada sirkulasi udara dan proses pertukaran gas yang pada akhirnya akan menghambat proses transportasi makanan kedalam sel-sel 
tubuh manusia manusia (Price, S.A., dan Wilson, L. M., 2005).

Asma bronkial merupakan penyakit inflamasi kronik yang menyebabkan terjadinya pembengkakan ataupun penyempitan pada saluran napas yang dapat menyebabkan peningkatan hiperreaktifitas serta hiperresponsif jalan napas yang menimbulkan gejala episodik berulang yang ditandai dengan mengi, sesak napas, dada terasa berat, dan batuk-batuk yang terutama terjadi pada malam hari, hiperinflasi, serta hiperventilasi pernapasan. Penyakit asma bronkial tidak dapat disembuhkan tetapi gejala dari penyakit asma bronkial tersebut dapat dikendalikan supaya tidak terjadi kekambuhan yang berulang (Junaidi, 2010).

Penyakit asma bronkial menjadi masalah utama yang sangat dengan ruang lingkup masyarakat pada masa ini karena populasi yang menderita asma semakin meningkat. Pada survey The Global Initiatiative for Asthma (GINA), kasus asma diseluruh dunia mencapai 300 juta jiwa dan diprediksi pada tahun 2025 pasien asma bertambah menjadi 400 juta jiwa (GINA, 2005). Dalam pernyataan lain dengan hasil survey yang berbeda yaitu memperkirakan bahwa ada 235 juta jiwa orang pada saat ini yang menderita asma dan sebagian besar asma terkait dengan kematian. Persentase terbanyak penderita asma ini terjadi di negara yang masih minim penghasilannya dan masyarakat yang lebih mayoritas menengah kebawah (WHO, 2013).

Prevalensi penderita asma menurut Riskesdas 2013 menunjukan bahwa prevalensi asma tertinggi terdapat di Sulawesi Tengah (7,8\%), kemudian Nusa Tenggara Timur $(7,3 \%)$, Yogyakarta $(6,9 \%)$, dan Sulawesi Selatan $(6,7 \%)$. Bali berada di urutan ke-6 dari 33 provinsi di
Indonesia dengan prevalensi 6,2. Dan untuk provinsi Sumatera Utara memiliki prevalensi asma sebesar 2,4\% (Riskesdas, 2013), di Rumah Sakit Grandmed Lubuk Pakam prevalensi pasien asma bronkial sebanyak 26 orang pada tahun 2020 dari tahun ke tahun jumlah asma semakin meningkat.

Air minum hangat adalah salah satu terapi non farmakologis yang dapat memberikan pengaruh oksigenisasi pada tubuh terutama pada organ pernapasan sehingga dapat membantu melancarkan jalan napas pada pasien asma bronkial yang mengalami gangguan pernapasan akibat adanya obstruksi ataupun faktorfaktor pemicu lainnya seperti reaksi alergi, infeksi virus, dan polusi udara. Air minum hangat adalah terapi yang tepat bagi pasien asma bronkial karena dengan minum air hangat partikelpartikel pencetus sesak dan cairan atau lendir dalam bronkioli akan dipecah (Muhammad, 2012).

Mengkonsumsi air minum hangat memberikan sensasi yang sangat cepat dalam menyebarkan gelombang panasnya ke seluruh organ tubuh manusia. Pada saat yang bersamaan pembuluh darah akan berdilatasi sehingga depat mengeluarkan keringat dan gas dari dalam tubuh. Organ dan sistem pernapasan merupakan salah satu organ yang mudah menangkap reseptor yang kuat untuk membedakan suhu panas dan suhu dingin. Air putih hangat bukan hanya sekedar benda yang kita minum saat kehausan atau setelah makan, air juga bukan sekedar wujud cair dengan sifat-sifatnya yang khas. Air putih merupakan substansi kimia yang memiliki rumus $\mathrm{H} 2 \mathrm{O}$. Air juga dapat disebut sebagai pelarut universal karena air putih dapat melarutkan banyak zat kimia. Air adalah pelarut yang kuat, mampu melarutkan banyak 
je is zat kimia. Zat-zat yang bercampur dan terlarut dengan baik dalam air (misalnya garam-garam), disebut sebagai zat-zat hidrofili, dan zat-zat yang tidak mudah bercampur dengan air (misalnya lemak dan minyak) disebut sebagai zat-zat hidrofobik (Muhammad, 2012).

\section{METODE}

Penelitian ini merupakan penelitian kuantitatif dengan rancangan pra eksperimen dan menggunakan rancangan penelitian pretest-posttest control group design dimana pada kelompok eksperimen diberikan air minum hangat sebelum dilakukan tindakan nebulizer, dan kelompok kontrol tidak diberikan air minum hangat sebelum dilakukan tindakan nebulizer. Populasi pada penelitian ini adalah semua pasien yang dirawat inap di Rumah Sakit Grandmed Lubuk Pakam. Sampel penelitian ini adalah sebanyak 30 responden yang dibagi menjadi 2 kelompok yaitu 15 orang untuk kelompok eksperiman dan 15 orang untuk kelompok kontrol.

Uji statistik yang digunakan dalam penelitian ini adalah SPSS 17.0. Analisis bivariat dengan Paired Sampel t-test dilakukan untuk melihat mana yang lebih besar pengaruh antara dua kelompok perlakuan tersebut.

\section{HASIL}

Tabel 1. Karakteristik Responden berdasarkan umur dan jenis kelamin pada kelompok eksperiman dan kelompok kontrol

\begin{tabular}{llll}
\hline No & $\begin{array}{l}\text { Karakteristik } \\
\text { Responden }\end{array}$ & $\mathrm{f}$ & $\%$ \\
\hline 1 & Usia & & \\
& $20-30$ tahun & 6 & 20,0 \\
& $31-40$ tahun & 11 & 36,7 \\
& $41-50$ tahun & 13 & 43,3 \\
\hline & Total & 30 & 100 \\
\hline
\end{tabular}

\begin{tabular}{llcc}
\hline 2 & Jenis kelamin & & \\
\hline & Laki-laki & 15 & 50.0 \\
& Perempuan & 15 & 50.0 \\
\hline Total & 30 & 100 \\
\hline
\end{tabular}

Berdasarkan tabel 1 responden yang umur 20-30 tahun adalah 6 responden dengan persentase $20,0 \%$, umur 31-40 tahun adalah 11 responden dengan persentase $36,7 \%$, dan umur 41-50 tahun adalah 13 responden persentasi $43,3 \%$. Sedangkan, jenis kelamin laki-laki sebanyak 15 orang dengan persentase $50 \%$ dan jenis kelamin perempuan sebanyak 15 orang dengan persentase $50 \%$.

Tabel 2. Rerata kelancaran jalan napas sebelum dan sesudah diberikan air hangat pada kelompok eksperiman

\begin{tabular}{cccc}
\hline Kadar $\mathrm{Hb}$ & $n$ & mean & $S D$ \\
\hline $\begin{array}{c}\text { Sebelum } \\
\text { intervensi }\end{array}$ & 15 & 31.60 & 1.724 \\
\hline $\begin{array}{c}\text { Sesudah } \\
\text { intervensi }\end{array}$ & 15 & 22.67 & 1.496 \\
\hline
\end{tabular}

Berdasarkan tabel 2. Diketahui

bahwa dari 15 responden diketahui rerata kelancaran jalan napas pada kelompok eksperimen sebelum nebulizer dengan memberikan air hangat dengan nilai mean 31.60 dengan standart deviasi 1.724, sedangkan nilai mean sesudah nebulizer yaitu 22.67 dengan standart deviasi sebear 1.496 .

Tabel 3. Rerata kelancaran jalan napas sebelum dan sesudah diberikan air hangat pada kelompok kontrol

\begin{tabular}{lccc}
\hline Kadar Hb & $n$ & Mean & $S D$ \\
\hline $\begin{array}{l}\text { Sebelum } \\
\text { intervensi }\end{array}$ & 15 & 32.80 & 1.474 \\
$\begin{array}{l}\text { Sesudah } \\
\text { intervensi }\end{array}$ & 15 & 32.73 & 2.314 \\
\hline \multicolumn{3}{c}{ Berdasarkan tabel 3. Diketahui } \\
bahwa dari 15 responden sebelum \\
nebulizer tanpa memberikan air hangat \\
rerata nilai mean 32.80 dengan
\end{tabular}


standart deviasi 1.474, sedangkan rerata nilai mean sesudah yaitu 32.73 dengan standart deviasi 2.314.

Tabel 4. Perbedaan peningkatan kelancaran jalan napas pada kelompok eksperiman dan kontrol

\begin{tabular}{cccccc}
\hline $\begin{array}{c}\text { Kelnca } \\
\text { ran } \\
\text { jalan } \\
\text { napas }\end{array}$ & Mean & SD & $\begin{array}{c}\text { Upp } \\
\text { er }\end{array}$ & $\begin{array}{c}\text { Low } \\
\text { er }\end{array}$ & $\begin{array}{c}P \\
\text { value }\end{array}$ \\
\hline $\begin{array}{c}\text { Ekperi } \\
\text { man } \\
\text { pre - } \\
\text { post }\end{array}$ & 8.93 & 1.43 & 9.72 & 8.17 & 0.00 \\
\hline $\begin{array}{c}\text { kontol } \\
\text { pre- } \\
\text { post }\end{array}$ & 0.06 & 2.52 & 1.46 & -1.32 & 0.92 \\
\hline
\end{tabular}

Berdasarkan tabel 4. Diketahui

bahwa perbedaan nilai rata-rata yaitu 8.93 pada kelompok eksperimen dengan standart deviasi 1.43, sedangkan pada kelompok eksperimen dengan rata-rata yaitu 0.06 dengan standart deviasi sebesar 2.52 . sedangkan pada kelompok kontrol nilai rata-rata 0.06 dengan standar deviasi 2.52. Hasil analisa data bivariat dengan menggunakan uji statistik Paired Sampel t-test yaitu pada kelompok eksperimen menunjukkan bahwa nilai $p$ value sebesar $0,00<0,05$ dan pada kelompok kontrol menunjukkan bahwa nilai $\mathrm{p}$ value sebesar 0,92>0,05).

\section{PEMBAHASAN}

\section{a. Karakteristik Responden}

Pada penelitian ini, berdasarkan hasil analisis distribusi frekuensi dapat dilihat bahwa sebagian besar subjek penelitian berusia 41-50 tahun. Pada penelitian ini, jumlah responden yang berjenis kelamin perempuan dan laki-laki pada kelompok eksperimen maupun kelompok kontrol berjumlah sama yaitu 15 orang laki-laki dan 15 orang perempuan. Penelitian terdahulu menunjukkan kaitannya dengan usia, bahwa $40 \%$ berusia 55-65 tahun, dan $40 \%$ berusia $20-35$ tahun.

Penelitian ini sejalan dengan penelitian (Marice, 2010) yaitu semakin meningkatnya umur maka semakin besar pula kemungkinan mendapatkan penyakit dan kekambuhan asma.

Penelitian lain oleh Muttaqin (2008) jumlah kejadian asma pada laki-laki lebih banyak dibandingkan dengan perempuan, sedangkan berdasarkan riwayat penyakit keluarga menunjukkan bahwa pada kelompok intervensi terdapat 9 orang (90\%) yang memiliki riwayat penyakit keluarga pada kelompok kontrol terdapat 8 orang $(80 \%)$ yang memiliki riwayat penyakit keluarga. dari hasil penelitianya dapat disimpulkan bahwa jenis kelamin laki-laki lebih berisiko terhadap riwayat penyakit.

\section{b. Perbedaan peningkatan kelancaran jalan napas pada kelompok ekperiman dan kelompok kontrol}

Dari hasil penelitian diperoleh bahwa perbedaan nilai rata-rata yaitu 8.93 pada kelompok eksperimen dengan standart deviasi 1.43, sedangkan pada kelompok eksperimen dengan rata-rata yaitu 0.06 dengan standart deviasi sebesar 2.52. sedangkan pada kelompok kontrol nilai rata-rata 0.06 dengan standar deviasi 2.52. Hasil analisa data bivariat dengan menggunakan uji statistik Paired Sampel t-test yaitu pada kelompok eksperimen menunjukkan bahwa nilai $p$ value sebesar $0,00<0,05$ dan pada kelompok kontrol menunjukkan bahwa nilai $\mathrm{p}$ value sebesar 0,92>0,05).

Pada kelompok eksperimen terjadi peningkatan kelancaran jalan napas Hal ini terbukti dari hasil perhitungan nilai respirasi rate pada kelompok ekperiman yang dinilai 
setelah diberikannya perlakuan yaitu mengalami penurunan menjadi normal, sedangkan pada kelompok kontrol yang tidak mengalami penurunan menjadi nilai normal pada perhitungan respirasi rate bahkan ada beberapa responden yang mengalami peningkatan pada respirasi rate walaupun sudah diberikannya tindakan nebulizer tanpa mengkonsumsi air minum hangat.

Hal ini sejalan dengan penelitian Herdina sri, dkk (2019) tentang pengaruh konsumsi air hangat terhadap frekuensi nafas pada penderita asma di Puskesmas sukamerindu Bengkulu dari hasil penenlitian menunjukkan bahwa pada kelompok intervensi terdapat perbedaan yang significant sedangkan pada kelompok kontrol tidak ada perbedaan karena pada kelompok kontrol tidak diberi minum air hangat pada saat penelitian.

Ketidaknyamanan pada saluran napas atau jalan napas merupakan salah satu masalah yang sering terjadi pada pasien Asma Bronkial terkait dengan menurunnya kualitas pola napas yang ditandai dengan sesak napas pada pasien asma bronkial. Untuk membantu kelancaran jalan napas pasien asma maka diberikan tindakan inhalasi yaitu dengan memberikan nebulizer. Namun jika hanya dengan tindakan nebulizer tidak secara maksimal membantu memperbaiki kualitas jalan napas pasien asma bronkial dengan demikian maka harus dibantu dengan cara mengkonsumsi air hangat sebelum pemberian nebulizer (Junaidi, Iskandar, 2010).

Mengkonsumsi air minum hangat dapat memberikan rasa yang sangat cepat dalam menyebarkan gelombang panasnya ke seluruh organ tubuh. Pada saat yang bersamaan pembuluh darah akan berdilatasi sehingga depat mengeluarkan keringat dan gas dari dalam tubuh. sistem pernapasan merupakan salah satu organ yang mudah menangkap reseptor yang kuat untuk membedakan mana suhu panas dan suhu dingin. Air putih hangat bukan hanya sekedar air yang kita minum saat kehausan atau setelah makan, air juga bukan hanya wujud cair dengan sifat-sifatnya yang khas tetapi air putih merupakan substansi kimia yang memiliki rumus $\mathrm{H} 2 \mathrm{O}$ yang dapat menyegarkan tubuh.

Pada pasien yang mengalami asma bronkial dapat diberikan minum air hangat untuk membantu memperlancar sirkulasi darah serta meningkatkan kelancaran jalan napas untuk memperbaiki kualitas pola napas pada pasien asma bronkial.

\section{KESIMPULAN}

Dari hasil penelitian dapat disimpulkan bahwa ada pengaruh mengkonsumsi air hangat sebelum pemberian nebulizer terhadap peningkatan kelancaran jalan napas pada pasien asma bronkial hal ini dibuktikan dengan hasil penelitian yang sudah uji secara statistik dengan hasil nilai pada kelompok eksperimen $\mathrm{p}$ value sebesar $0,00<0,05$ dan pada kelompok kontrol $p$ value sebesar $0,92>0,05)$, dimana pada kelompok ekperiman diberikan air hangat sedangkan pada kelompok kontrol tidak diberikan air hangat sebelum nebulizer.

\section{DAFTAR PUSTAKA}

Guyton, A.C., \& Hall, J.E. (2006). Buku Ajar Fisiologi Kedokteran (edisi 9). Jakarta: EGC.

Hardina sri, Septiyanti \& Wulandari Dwi (2019). Pengaruh konsumsi air hangat terhadap frekuensi nafas pada pasien asma di Puskesmas 
Sukamerindu Kota Bengkulu. Journal of Nursing and Public Health Vol. 7 No.2.

Junaidi, Iskandar. (2010). Penyakit Paru Dan Saluran Napas. Jakarta:Bhuana Ilmu Poupuler.

Marice. (2010). Faktor-Faktor Yang Berhubungan Dengan Penyakit Asma Di Indonesia. Media Litbang Kesehatan Volume XX Nomor 1.

Muhammad, As'adi. (2012). Kedahsyatan Air Putih Untuk Ragam Terapi Kesehatan. Yogyakarta: DIVA Press.

Notoatmodjo. (2012). Metodologi Penelitian Kesehatan. Jakarta: PT. Rineka Cipta.

Price, S.A., dan Wilson, L. M., (2005). Patofisiologi: Konsep Klinis Prosesproses Penyakit, Edisi 6, Vol. 2, diterjemahkan oleh Pendit, B. U.,

Hartanto, H., Wulansari, p., Mahanani, D. A.,Penerbit Buku Kedokteran EGC, Jakarta

Riskesdas. (2013). Badan Penelitian dan Pengembangan Kesehatan. Kementrian Kesehatan RI

Tahun 2013. Available : http://www.depkes.go.id/resou rces/ download/general/hasil\%Riske sdas \%202013.pdf (12 Maret 2017). Somantri, Irman. (2009). Asuhan Keperawatan Pada Klien Dengan GangguanSistem Pernapasan. Edisi 2. Jakarta : Salemba Medika.

WHO. (2013). Media Centre Asthma. Available: http://www.who.int/mediacentr e/fa ctsheets/fs307/en/ (12 Maret 2017). 